\title{
Seed Production in Grafted Clonal Orchards at Longlac, Ontario
}

\author{
by
}

\author{
J.A. McPherson 1†, E.K. Morgenstern², and B.S.P. Wang ${ }^{3}$
}

\begin{abstract}
One seed orchard each of black spruce (Picea mariana) [Mill.] B.S.P.) and white spruce (Picea glauca) [Moench] Voss) was established in northern Ontario gradually during the $1958-78$ period. Each species was represented by approximately 45 clones and 450 ramets. During the whole period, records were kept of cone production by individual ramets and of seed production by clones expressed as average number of seeds per cone extracted and germinated. Substantial cone production began 8 years after grafting in black spruce and after 10 years in white spruce. The figures indicated that a clonal orchard of black spruce planted at $5 \times 5 \mathrm{~m}$ spacing (400 ramets) produces approximately 1 million sound seeds per ha per year; the white spruce equivalent is 900000 . Conditions of cone development and cone storage and damage by insects and fungi can reduce germination of the sound seed harvested by about $20 \%$.
\end{abstract}

\section{Résumé}

Un verger à graines d'épinette noire (Picea mariana), Mill. B.S.P. et un autre d'épinette blanche (Picea glauca) Moench Voss, ont été établis progressivement entre 1958 et 1978 dans le nord de l'Ontario. Chaque espèce était représentée par à peu près $\mathbf{4 5}$ clones et $\mathbf{4 5 0}$ "ramets". Pour l'ensemble de la période, des données furent prises par "ramets" et par clone sur la production de cones que l'on a exprimée en nombre moyen de graines extraites et germées par clone. Une production substantielle de cones survient respectivement huit et dix ans après le greffage sur l'épinette noire et sur l'épinette blan. che. Les chiffres indiquent que le verger d'épinette noire avec un espacement de 5 sur 5 m (400 "ramets") donne environ 1 million de graines vivantes par hectare et par an, alors que l'épinette blanche en produit dans les mêmes conditions 900000 . Les conditions de développement et d'entreposage des cones et les dommages des insectes et des champignons peuvent réduire de $20 \%$ la germination des graines vivantes récoltées.

\section{Introduction}

One of the first requirements of any silvicultural program is a reliable seed supply. The current increase in reforestation and simultaneous rapid development of

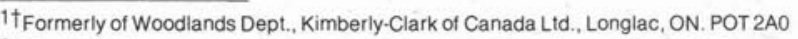

2 Faculty of forestry, University of New Brunswick, Fredericton, NB. E3B 6C2

3 Canadian Forestry Service, Petawawa National Forestry Institute, Chalk River. ON. KOJ 1 JO
}

breeding programs in Canada make it difficult to plan areas for seed orchards particularly since expected seed production is not well documented. Information on seed production in orchards is therefore urgently needed.

In 1958 Kimberly-Clark Ltd. and the Geraldton District of the Ontario Ministry of Natural Resources jointly initiated a plus-tree selection program in black spruce and white spruce and subsequently Kimberly-Clark established a clonal orchard for each species. This paper reports on seed production in these orchards.

\section{Review of Literature}

Seed production in black and white spruce has been studied extensively but most reports are based on production in natural stands or plantations (Haig 1969, Zasada and Viereck 1970, Manley 1978, Wang 1978, Haavisto 1980, Simpson 1981). These reports indicate that the number of current year's sound or full seeds per cone in black spruce ranges from 3 to 60 and in white spruce from 6 to 62; age of trees, seed years and insect damage having an important effect.

Reports from seed orchards are few. In a study of in: itial cone production in a clonal orchard of the Ministry of Natural Resources near Thunder Bay, Kokocinski (1978) found that an average of 108 cones was produced by ramets 4 to 10 years after grafting. Production in the most recently grafted ramets was very low. He concluded that it takes 8 to 10 years from grafting or 6 to 8 years from outplanting of ramets before cone production begins. In another study with white spruce in Wisconsin, individual ramets yielded an average of 98 cones 9 years after grafting. There were 26 sound seeds per cone following open pollination, and 45 seeds per cone after controlled pollination. It was predicted that during a good flowering year, a 1-ha seed orchard at $5 \times 5 \mathrm{~m}$ spacing could produce in excess of 40,000 cones and 1 million sound seeds less than 10 years after grafting (Nienstaedt and Jeffers 1970).

\section{Orchard Establishment and Maintenance}

The orchard area is in Site Region $3 W$, Geraldton Site District (Lat. $49^{\circ} 47^{\prime}$, Long. $86^{\circ} 30^{\prime}$ ) (Hills 1961), about 11 $\mathrm{km}$ east of Longlac. It is situated in a glacial outwash plain with medium to fine silty sand and a medium to low lime content. Surrounding forest types are jack pine (Pinus banksiana Lamb.) - black spruce with scattered balsam fir (Abies balsamea [L.] Mill.) and white spruce. The water table of these sands is not deep and their productivity is fairly high; at $80-100$ years standing volumes of $300-400 \mathrm{~m}^{3} /$ ha are observed.

Tree selection was carried out in the standard manner specified for Ontario (Carmichael 1960). Scions were grafted from 1960 on and the ramets planted into the orchard one to two years later. Selection, grafting, and planting were carried out gradually over the 20-year- 
period 1958-78: new clones were added to the orchard almost every year or additional ramets of old clones were supplied by re-grafting from the clone bank (Humphreys 1967). This produced an orchard of uneven age. The orchard area for each species was slightly larger than 1 ha and the two orchards were situated side by side. Arrangement of clones was by simple randomization, each clone being represented by several single ramets in different parts of the rectangular orchard.

Flowering and cone production began as early as 1964 particularly in black spruce. From 1968 on, standard N-P-K fertilizers, such as "10-10-10", were applied annually. Since 1974 the more complete CIL fertilizer "'Evergreen 6-9-6" was given. This contains nine nutrient elements. Foliar analyses in September 1976 revealed that according to established standards (Swan 1970, 1971), nitrogen and magnesium were deficient in the black spruce orchard and nitrogen deficient in the white spruce orchard. The concentration of calcium was high and that of other elements sufficient. The results also compared well with earlier samples taken in pulpwood stands of the same general area (Lowry 1972).

\section{Methods}

The gradual establishment of both orchards from 1960 to 1978 resulted in an age that increased irregularly from one year to the next, depending upon the number of ramets added each year. A weighted mean age was therefore calculated for each orchard each year, and all age-related calculations were based on it. A smaller sample with uniform age was provided by all ramets grafted in 1960.

Cones of both species were shipped to the seed extractory at Petawawa during the winter following seed collection and air-dried on screened trays for 2-4 months before seed extraction and processing. While white spruce cones were opened at room temperature ranging from $22^{\circ} \mathrm{C}$ to $27^{\circ} \mathrm{C}$, black spruce cones were soaked in $32^{\circ} \mathrm{C}$ water for 90 minutes followed by kiln drying at $40^{\circ} \mathrm{C}$ for 2 hours and at $60^{\circ} \mathrm{C}$ for 14 hours with a relative humidity of approximately $19-25 \%$. Extracted seeds were moist dewinged and conditioned to a moisture content of 5 to $8 \%$ wet weight.

Germination tests were made according to the rules of the International Seed Testing Association (1976) and included only clones with seed yield of $10 \mathrm{~g}$ or more for the 1972, 1975, 1976, 1977 and 1979 crop years. Seeds were either left untreated before germination or prechilled at $2-4^{\circ} \mathrm{C}$ for three weeks. Germination counts were made weekly for three weeks and seeds were considered germinated when their radicle and hypocotyls were well developed and cotyledons visible (Wang 1976). At the end of each test period, all ungerminated seeds were cut and classified as fresh, dead or empty.

\section{Results}

Flowering of the black spruce ramets began in 1964 and of the white spruce in 1967, but was at first too scarce to warrant cone collections. Cone collections and systematic counts of cone production for each ramet were begun for black spruce in 1969 and white spruce in 1970 , and except in 1978 (a poor cone year), continued every year for both species to 1979.

Basic statistics from the two orchards are given in Table 1 and Figure 1. In part $A$ of the table, results from the whole orchard are given for each species. Part B lists results from the oldest ramets grafted in 1960. Part C contains a projection of annual seed production for 1 ha of orchard area. As shown in A, the average number of sound seeds per cone was 13 for white spruce and 11 for black spruce.

In addition to the data recorded over the years, the results from the heavy 1980 white spruce cone crop are of interest when only total volumes could be recorded (34 hl). If we assume 20000 cones per hl (Forest Resources Branch 1977), these contain approximately $34 \times 20000$

Table 1. Summary of results and projections.

\begin{tabular}{|c|c|c|c|}
\hline & Variable & $\begin{array}{c}\text { Black spruce } \\
\text { orchard }\end{array}$ & $\begin{array}{c}\text { White spruce } \\
\text { orchard }\end{array}$ \\
\hline & A. Whole orchard (ramets of all ages) & & \\
\hline 1. & 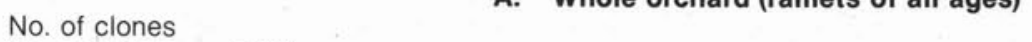 & 45 & 51 \\
\hline 2. & No. of ramets -1979 & 436 & 485 \\
\hline 3. & Earliest collected cone crop (year) & 1964 & 1970 \\
\hline 4. & Average number of years from grafting to & 急 & 10 \\
\hline \multirow[t]{2}{*}{5.} & No. of cones per flowering ramet per year & & \\
\hline & $(1969-1979) \quad-\quad$ range & $5-598$ & $12 \cdot 456$ \\
\hline \multirow[t]{3}{*}{6.} & No. of sound seeds per cone over all clones & 103 & 151 \\
\hline & in any year $\quad-$ range & $2-28$ & $11 \cdot 14$ \\
\hline & - mean & 11 & 13 \\
\hline
\end{tabular}

\section{B. Oldest part of orchard (ramets from grafting in 1960)}

1. No. of clones

2. Total no. of ramets

3. No. of years of cone production as fraction of total years (averaged over all ramets)

4. Per cent of productive ramets in best year

5. Mean no. of cones per ramet per year and period

6. Mean no. of counds seeds per cone

$\begin{array}{rr}5 & 8 \\ 17 & 39 \\ 9 / 15 & 6 / 9 \\ 100(1979) & 100(1976) \\ 226(1969-79) & 174(1970-79) \\ 12 & 10\end{array}$

\section{Projection of annual production per ha}

1. Mean annual seed production - all ramets

$436 \times 226 \times 11=$

1083896

2. Mean annual seed production per ha (spacing $5 \times 5 \mathrm{~m}=400 /$ ha)
$400 \times 226 \times 11=$

994000
$485 \times 174 \times 13=$ 1097070

$400 \times 174 \times 13=$ 904800 


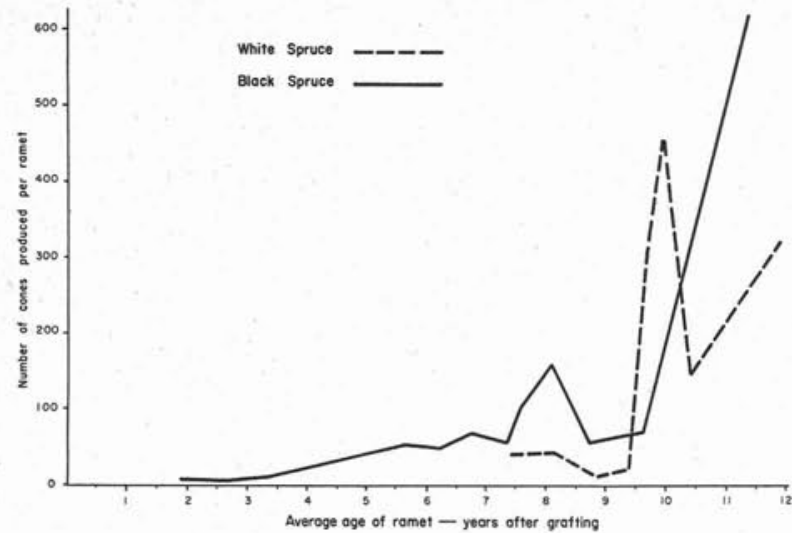

Figure 1. The timing of cone production after grafting.

$=680000$ cones or $680000 / 485=1402$ cones per ramet.

As shown in Table 2, seed quality in terms of germinability was good for both species of all crop years tested except for 1979 white spruce and for 1972 and 1979 black spruce. The germinability of 7 clones of the 1975 and 1976 white spruce seeds ranged from $61 \%$ to $98 \%$ with an over-all average of $94 \%$ when the seeds were pre-chilled. Pre-chilling improved the germination of white spruce by $6 \%$ when averaged over all years. Cutting tests and $x$-radiographs revealed large numbers of under-developed seeds or seeds of low vigor, particularly in some clones. Possible reasons are adverse climatic conditions at the time of cone development, insect damage, or improper cone handling resulting in molding. Routine observations indicated that the 1974 black spruce cone crop was severely damaged by the cone rust (Chrysomyxa pirolata Wint.) and the cone worm (Dioryctria spp.). A more systematic assessment of insect and disease damage to the 1980 crop by Dr. Fogal ${ }^{4}$ indicated that $97 \%$ of the black spruce cone samples

${ }^{4}$ Unpublished data by W.H. Fogal, 1981, Petawawa National Forestry Institute, Chalk River, Ontario. were infested with rust, and $98-99 \%$ of both black and white spruce cones were attacked by insects although seed losses were only $18 \%$ for black spruce and $45 \%$ for white spruce. The major insects found in the cones were cone maggot (Hylemya anthracina [Czerny]), seed midge (Phytophaga carpophaga [Tripp]), and seed worm (Laspeyresia youngana [Kearfott]). Based on part C of Table 1 and Table 2, the mean annual production per ha of germinable seed from the orchard will be $994,000 \times .95$ $=944300$ black spruce and $904800 \times .79=714792$ white spruce.

\section{Discussion}

It took about 8 years from grafting in black spruce and 10 years in white spruce to produce substantial numbers of cones and seed. For the whole orchard, the mean number of cones per flowering ramet over all years was 103 for black spruce and 151 for white spruce. This is still below the expected mean: both orchards averaged less than 12 years from grafting in 1979, the last year of records, and part $\mathrm{B}$ of Table 1 indicates that in the ramets grafted at the earliest date (1960), mean numbers of cones per ramet were 226 in black spruce and 174 in white spruce.

With respect to crop frequency, it is seen that once flowering had begun, the average black spruce ramet flowered in 9 out of 15 years and the average white spruce in 6 out of 9 years. The ramets grafted in 1960 all flowered in the best crop year. Thus the phenomenom of delayed flowering or infertility of individual clones was not observed here.

There is a remarkable difference between species in the range of the number of seeds per cone produced, i.e. 2-28 for black spruce versus $11-14$ for white spruce. Since black spruce is very common in the wild stands surrounding the orchards but white spruce rare, the quantity of available pollen was not the only important factor. Probably female flower development and insects and diseases were equally or even more significant.

Part C of Table 1 predicts that both orchards will produce in excess of 1 million seeds per annum on an area slightly larger than 1 ha about 20 years after grafting.

Table 2. Germination capacity of white and black spruce seed from selected clones of Kimberly-Clark seed orchard by different seed crop years and pretreatment.

Species Clone Germination \% after 3 weeks by seed year and treatment ${ }^{1}$

\begin{tabular}{|c|c|c|c|c|c|c|c|c|c|c|c|c|}
\hline & \multirow{3}{*}{. } & \\
\hline & & \multirow{2}{*}{$\begin{array}{c}1972 \\
U\end{array}$} & \multicolumn{2}{|c|}{1975} & \multicolumn{2}{|c|}{1976} & \multicolumn{2}{|c|}{1977} & \multicolumn{2}{|c|}{1979} & \multicolumn{2}{|c|}{ All years } \\
\hline & & & $U$ & C & U & C & $U$ & C & U & C & U & C \\
\hline Black & B & - & 98 & 98 & - & - & 99 & 99 & 99 & 98 & 98.7 & 98.3 \\
\hline \multirow{8}{*}{ Spruce } & 19 & 89 & 99 & 100 & 98 & 99 & 98 & 100 & 76 & 70 & 92.0 & 92.3 \\
\hline & 23 & 78 & 99 & 98 & 99 & 99 & 99 & 100 & 93 & 91 & 93.6 & 97.0 \\
\hline & 367 & 44 & 91 & 95 & 99 & 99 & 99 & 99 & 79 & 74 & 82.4 & 91.8 \\
\hline & 384 & - & 94 & 94 & 99 & 98 & - & - & 96 & 97 & 96.3 & 96.3 \\
\hline & 385 & - & 95 & 95 & 97 & 99 & 99 & 99 & 91 & 91 & 95.5 & 96.0 \\
\hline & 393 & 79 & 91 & 93 & 99 & 98 & - & - & 88 & 87 & 89.3 & 92.7 \\
\hline & 394 & 96 & 94 & 92 & 98 & 99 & - & - & 92 & 87 & 95.0 & 92.7 \\
\hline & All & 77 & 95 & 96 & 98 & 99 & 99 & 99 & 89 & 87 & 92.9 & 94.6 \\
\hline White & 15 & - & 92 & 97 & 77 & 98 & - & - & 46 & 38 & 71.7 & 77.7 \\
\hline \multirow[t]{8}{*}{ Spruce } & 20 & - & 91 & 94 & 95 & 97 & - & - & 40 & 50 & 75.3 & 80.3 \\
\hline & 21 & - & 94 & 90 & 87 & 86 & - & - & 54 & 65 & 78.3 & 80.3 \\
\hline & 368 & - & 75 & 96 & 89 & 99 & - & - & 70 & 72 & 78.0 & 89.0 \\
\hline & 380 & - & 85 & 92 & 61 & 93 & - & - & 30 & 27 & 58.7 & 70.7 \\
\hline & 390 & - & 78 & 94 & 89 & 95 & - & - & 17 & 21 & 61.3 & 70.0 \\
\hline & 398 & - & 94 & 95 & 72 & 87 & - & - & 18 & 26 & 61.3 & 69.3 \\
\hline & Bulk & - & - & - & - & - & 92 & 91 & - & - & 92.0 & 91.0 \\
\hline & All & - & 87 & 94 & 81 & 94 & 92 & 91 & 39 & 43 & 72.1 & 78.5 \\
\hline
\end{tabular}

$1 \mathrm{U}$ - untreated; $\mathrm{C}-$ chilled for 3 weeks at $2-4^{\circ} \mathrm{C}$. 
Reduced to 1 ha (400 ramets at $5 \times 5 \mathrm{~m}$ spacing), production will be about 994,000 seeds in black spruce and 905000 in white spruce. However, the white spruce production is still increasing as indicated by the large 1980 cone crop with 1402 cones per ramet. Therefore, average per-annum production in white spruce may be larger than predicted here.

Comparisons with the data provided by Nienstaedt and Jeffers (1970) and Kokocinski (1978) indicate that their estimates do not differ greatly. These authors lacked long-term records but their results were similar.

\section{Conclusions}

This paper reports for the first time information systematically developed in clonal orchards over a period of 20 years. It indicates when flowering and seed production begin and the average number of cones per ramet and seeds per cone. Although long-term observations on seed and cone insects and diseases were not made, the assessment of losses in the 1980 crop indicated the seriousness of the pest problems and the need for effective control. The orchard area was well chosen and seed production figures are probably representative of similar conditions in boreal forests.

\section{Acknowledgement}

We wish to thank Dr. W.H. Fogal, Petawawa National Forestry Institute, for identification of cone insects named in this report; Miss F. Sheridan and Messrs. B.D. Haddon, E.L. Gilchrist and W. Selkirk of the same Institute for their technical assistance in cone handling, seed processing, germination and compilation of data.

Our co-author Angus McPherson died recently. It was largely his initiative and foresight to keep meticulous records of cone production for individual ramets over a long time that made this paper possible - something that to our knowledge no one else has done in Canada. We will long remember him as a very fine forester.

\section{References}

Carmichael, A.J. 1960. Report to Committee on Forest Tree Breeding, August 1960. Proc. Seventh Meet. Comm. Forest Tree Breed. Canada, Part II, p. B-10 to B-10.

\section{TECHNICAL REPRESENTATIVE}

Largest distributor of Silviculture, Reforestation, Forest Inventory, Scaling and allied equipment in Canada requires a self-motivated Technician to carry out its exciting new Marketing plans.

If you have a post secondary degree in Forestry, we would like to hear from you.

Experience in Marketing an asset. Training provided.

Territory: Ontario

Excellent monetary rewards and potential for growth. Comprehensive benefit program.

For further details, please submit resume to:

CANADIAN FORESTRY EQUIPMENT LTD.

2567 Drew Road

Mississauga, Ontario L4T 1G1
Forest Resources Branch. 1977. Manual of seed collecting. Ontario Ministry of Natural Resources. 26 p.

Haavisto, V.F. 1980. The retention of seed viability in semiserotinous black spruce cones. IUFRO Working Party S.2.01.06 "Seed Problems" Symp. on Forest Tree Seed Storage, Petawawa, Sept. 1980. Preprint No. 22. 8 p.

Haig, R.A. 1969. Trials of mechanical collection of black spruce and jack pine cones. Can. For. Serv. Inf. Rep. 0-X-12: 15 p.

Hills, G.A. 1961. The ecological basis for land-use planning. Ontario Ministry of Natural Resources, Research Rep. No. 46. 204 p.

Humphreys, E.R. 1967. An industrial tree-improvement program in northern Ontario. Proc. Tenth Meet. Comm. Forest Tree Breed. Canada, Part 2, p. 85-86.

International Seed Testing Association. 1976. International rules for seed testing, 1976. Seed Sci. \& Technol. 4(1): 3-180.

Kokocinski, G.H. 1978. Black spruce cone production in the Mattawin clonal seed orchard. Ont. Min. Nat. Res., For. Resources Br., Thunder Bay, Ont. $10 \mathrm{p}$.

Lowry, G.I. 1972. Forest soil-site studies. V. Black spruce productivity as related to soil and other site factors. Pulp and Paper Res. Inst. Canada, Woodlands Rep. WR/44. 49 p.

Manley, A.L. 1978. Seed yield of immature black spruce (Picea mariana [Mill.] B.S.P.) plantations in south-central New Brunswick. Univ. of New Brunswick, Faculty of Forestry BScF thesis. $31 \mathrm{p}$.

Nienstaedt, H. and R.M. Jeffers. 1970. Potential seed production from a white spruce clonal seed orchard. Tree Planters' Notes 21:15-17.

Simpson, J.D. 1981. Site selection for black spruce (Picea mariana [Mill.] B.S.P.) seedling seed orchards and management techniques for seed orchards in New Brunswick. MF Rep., Univ. of New Brunswick. $81 \mathrm{p}$.

Swan, H.S.D. 1970. Relationships between nutrient supply, growth and nutrient concentrations in the foliage of black spruce and jack pine. Pulp and Paper Res. Inst. Canada, Woodlands Pap. No. 19. 46 p.

Swan, H.S.D. 1971. Relationships between nutrient supply, growth and nutrient concentrations in the foliage of white and red spruce. Pulp and Paper Res. Inst. Canada, Woodlands Pap. No. 29. 27 p.

Wang, B.S.P. 1976. Dormancy and laboratory germination criteria of white spruce seed. Proc. 2nd IUFRO Int. Symp. on Physiology of Seed Germination, Yamanaka Lake, Japan. 1976. p. $179-188$

Wang, B.S.P. 1978. Seed yield and germination requirements of Alberta white spruce and lodgepole pine. Alberta Dept. Energy and Nat. Res. Rep. No. 92. 26 p.

Zasada, J.C. and L.A. Viereck. White spruce cone and seed production in Interior Alaska, 1957-68. USDA For. Serv. Res. Note PNW-129. 11 p.

\section{MARKETING PROFESSIONAL GREENHOUSE SYSTEMS}

National distributor of Forestry, Reclamation and Greenhouse equipment requires Horticulturist with hands-on experience in designing and operation of Greenhouse systems.

We are seeking a results-oriented individual with a proven record of achievement. Above average communication skills are necessary, to help in the marketing of this equipment to the Forest Industry.

This is a career opportunity in a rapidly growing field, with high income potential. We offer an excellent salary, and a comprehensive benefit package.

If you are mobile and willing to relocate, consider joining our team, and expand your career.

\section{Send resume to:}

CANADIAN FORESTRY EQUIPMENT LTD. 2567 Drew Road Mississauga, Ontario L4T 1G1 